Based on a careful analysis of German diplomatic documents, the narrative concentrates on the Russo-German tension following the Congress of Berlin, the personal animosity and rivalry between Bismarck and the Russian foreign minister, A. M. Gorchakov, and relations between Berlin and Vienna. A great deal of attention is also given to the controversy over German investments in the Rumanian railroads and to their relevance for German foreign policy. In general, Waller gives an able account of the events of the period. However, it must be strongly emphasized that this book is designed for specialists in diplomatic history with a good knowledge of the issues at stake. Waller does not discuss the general policy of the countries involved, or their aims and methods. Adequate background information on the specific issues with which the study deals is also missing. For example, the reader is not given an explanation of the background of the complicated and controversial Rumanian railroad problem, the settlement of the Silistrian boundary, and the terms of the Treaty of Berlin. In addition, some objections could perhaps be made to the treatment of Gorchakov. Considerable attention is paid to the "two chancellors' war" without any indication that there is a great deal of evidence that the Russian chancellor was by this time sick, feeble, and even senile-in no way a match for his vigorous and aggressive opponent.

With these reservations in mind, this book should definitely be read by anyone interested in diplomatic relations in the years 1878-80. It is based on thorough research in London, Paris, and Vienna, as well as on German documentation.

BARBARA JELAVICH Indiana University

\title{
DEUTSCHE RUSSLANDPOLITIK: DAS SCHEITERN DER DEUTSCHEN WELTPOLITIK UNTER BULOW 1900-1906. By Barbara Vogel. Studien zur modernen Geschichte, vol. 11. Düsseldorf: Bertelsmann Universitätsverlag, 1973. 335 pp. DM 38, paper.
}

Barbara Vogel, a student of Fritz Fischer, has presented us with an exhaustive, closely reasoned examination of the role vouchsafed to Russia in Bülow's Weltpolitik. But it would be unfair to the author to think of her work as nothing more than a study, however excellently done, of Russo-German relations in the Bülow era. Her larger aim is to relate German domestic and foreign policies to each other and to perceive these policies, in turn, as part of a consistent design to gain Russian support for the ultimate destruction of English hegemony, and it has been, for the most part, brilliantly achieved. In her eagerness to break with the old Primat der Aussenpolitik, however, she has perhaps swung too heavily in the direction of an Interressenpolitik carried out "on the order of and for the benefit of the ruling elements of the state." If only it were all so easy. Then one would merely have to fathom the interests of these elements and, presto, the policy would become obvious. In actuality, her own scholarship and sophistication have led her far beyond such limited premises.

Vogel demonstrates convincingly that Björkö, far from being "an escapade of personal imperial policy," as it has been described so often, was a logical outcome of Bülow's earlier policies toward Russia. Fully conscious of the ironies of history, she notes almost with relish how one of Bülow's greatest domestic triumphs, the fusion of agrarian and industrial interests in support of the Russian 
trade treaty of 1904 , contributed not only to the ultimate alienation of the very quarry it was meant to attract, but also to Bülow's final loss of domestic support when the always uneasy partnership of temporary interests fell apart.

Vogel also effectively cautions the reader not to impose the German Russlandbild of the last decade before the war upon the earlier Bülow era. Racialist predictions of an inevitable war between German and Slav, or Social Democratic calls for a struggle against tsarism, while not wholly new, achieved a louder voice precisely because the fiascos of 1904-5 and Algeciras had proven the illusory nature of Bülow's policy of courtship and threat.

The critical reader can scarcely think of an important source which the author has neglected to consult. The judicious use of the archives in Bonn-particularly those pertaining to Germany's Anleihepolitik, the rich vein of material on commercial and industrial relationships at Potsdam, and the holdings at Merseburg on Russian-Prussian cooperation against revolutionary and terrorist activities, greatly helped in the fashioning of a work of substance and conviction.

Hans HeILBRon Ner

University of New Hampshire

THE TIDE AT SUNRISE: A HISTORY OF THE RUSSO-JAPANESE WAR, 1904-1905. By Denis and Peggy Warner. New York: Charterhouse Publishers, 1974. xi, 627 pp.

This book is an attempt to place an essentially military history of the Russo-Japanese war into a political context. The title of the first chapter, "The First Pearl Harbor," furnishes a major clue not only to the double military-political threads that run through the book but also to the use of questionable historical parallels. An exposition of how Japan, Korea, Russia, and China reached "The First Pearl Harbor" is then presented in the next hundred pages. Interspersed through what is predominantly a military narrative are a number of vignettes, such as the story of Colonel Akashi Motojiro and the Japanese intelligence effort in Europe. The book concludes with one chapter on the ending of the war at the Portsmouth Conference and another under the heading of "Aftermath," which hastily brings the "story" down to the energy crisis of 1973.

What, specifically, is the story the authors are telling? Is the volume an attempt to write a chapter in the history of warfare by comparing the strategic, tactical, and technical accomplishments of two antagonists? Is it instead a story, with military emphasis, of Japan's effort to seize a fleeting opportunity to win a place in the world? Or is it an attempt to make military history more readable by enfolding it in a political format? The answers are not obvious, and the authors hint at each of these purposes as they recount how the Japanese David went forth to do battle with the Russian Goliath. This lack of a clear, central theme also means a lack of integration of the material in the thirty-three chapters. Although a more consistent narrative would have been desirable, there are passages which are quite adequately brought into focus. One example is the reference to the concluding stages of the Portsmouth Conference when Japanese willingness to compromise on Sakhalin and indemnity demands was necessarily influenced by the improved military position of the Russians in Manchuria.

The military narrative, although episodic with too little attention paid to general strategy, makes a positive contribution in the treatment of individual 